\title{
Making and Implementing an Environmental Studies Database for Teacher Librarians: Metadata Education for Teacher Librarians
}

\author{
Fukuji Imai, Anne McKnight, Kuniharu Tabata, Shinji Iwamasa \\ Shirayuri University \\ 1-25, Midorigaoka, Chofu-shi, Tokyo, 182-8525 \\ Japan, \\ fukuji@shirayuri.ac.jp
}

\begin{abstract}
Metadata encodes important knowledge for school library education. This study framed two questions: 1. How are metadata treated in teacher librarian textbooks? 2. What teaching materials are best for teacher librarians' metadata education? To answer question one, we investigated the regulation of subject and content by Ministry of Education in Japan and we reviewed teacher librarian textbooks. To answer question two, we created an environmental studies database that included geographical metadata, and then surveyed undergraduate students to learn how the database was utilized. In conclusion, we recommend that future studies of metadata examine both how metadata are defined and how metadata are used in particular situations.
\end{abstract}

Keywords: Metadata, Teacher Librarian, Library Education, Instructional Materials, Textbook Research 


\section{Introduction}

\section{The Need for Metadata and New Media Coursework}

The American Association of School Librarians (AASL) Standards for the 21st-Century Learner in Action lists four standards of learner skills, each of which has four strands (American Association of School Librarians, 2008). These strands are skills, dispositions in action, responsibilities, and self-assessment strategies. Standard one, "Inquire, think critically and gain knowledge," includes the disposition "demonstrate creativity by using multiple resources and formats." Therefore, children and students require knowledge of multiple resources and information formats.

Metadata are a significant aspect of multiple resources and format. The word "Metadata" is defined in the Library and Information Science (LIS) glossary as follows: "Metadata are structured information used to find, access, use and manage information resources, primarily in a digital environment" (Feather and Sturges, 2003, p. 417)

Generally in LIS, metadata are related to a new cataloging concept, such as Functional Requirements for Bibliographic Records (FRBR), that is able to catalog audio-visual, digital contents (Wolfgang and Mechtild, 2015, p. 566-585). The Dublin Core Metadata Element Set (DCMES) is the scheme of metadata. The DCMES includes a vocabulary of fifteen properties. We can easily imagine the importance of properties such as Title, Creator, and Publisher. Coverage is also an important property for organizing digital media. Coverage can include a named place or a location specified by its geographic coordinates (The Dublin Core Metadata Initiative, 2012).

Knowledge of how to manage new media has become indispensable for school library professionals. Metadata, for example, are key for handling digital media other than books, and may include bibliographic, graphical, and geographic information. Metadata summarize basic information, which makes finding and working with particular instances of data easier.

Institutions training school library professionals need to include coursework about how librarians can explain metadata to their students. As the World Wide Web has impacted the entire world, Japanese teacher librarians need to understand how to use this information storehouse. 


\section{Training of Japanese School Library Professionals}

In Japan, there are two types of school library professional. Shisho-kyouyu is the Japanese teacher librarian, a professional assigned to schools with more than 11 classes.

Shisho-kyouyu are also subject teachers, and most of them do not work in the library on a daily basis. The other professional is the gakko-shisho. This is the Japanese school librarian, who maintains the school library and does not teach. Generally speaking, shisho-kyouyu are so busy with other school duties that they find it difficult to concentrate on their library tasks (Sakai, Namura, and Kitamura, 2002).

From 2003 to 2006, the Japan Society of Library and Information Science, the nationwide academic society for library and information science in Japan, took the initiative of carrying out the three-year project called Library and Information Professions and Education Renewal (LIPER). The project consisted of various research teams and studied various aspects of the library profession.

The team called LIPER-SL (LIPER School Library team) proposed a new model for the school library professional in Japan, the School Information Specialist. The School Information Specialist must handle three functions: information and knowledge management, information and knowledge sharing, and information and knowledge utilization. The first function includes "designing an effective learning environment with resources ranging from printed materials to digital information for students and teachers" (Y. Kasai, 2006, p. 441).

The School Information Specialist should deal with both printed materials and digital information, with related metadata knowledge. However, despite this important suggestion of the team, there have been no changes in the curriculum for educating shisho-kyouyu.

The system of shisho-kyouyu has many challenges that we are attempting to address in this study. For the sake of clarity, we will hereafter refer to shisho-kyouyu as teacher librarian.

\section{Problem Statement}

There are many articles about the education and the practice of the teacher librarian. Matsuzaki and Shibata have reviewed textbooks for teacher librarian education. They focused on organizing information and information retrieval in textbooks (Matsuzaki and Shibata, 2012). 
Tokuda and Maeda have developed a curriculum of newspapers in education (NIE) in teacher librarian courses (Tokuda and Maeda, 2012). Kudo has developed education exercises in the creation of library pathfinders for information seeking (Kudo, 2014). However, few attempts have been made to deal with the question of metadata education to teacher librarian students in Japan.

This paper examines two questions.

1. How is the topic of metadata covered in teacher librarian textbooks?

2. What kind of teaching materials are better for metadata education of teacher librarians?

This paper is organized as follows. To address question 1, in Section 2 and 3 we evaluate a regulation of subject content in teacher librarian education by the Ministry of Education (MoE), and review textbooks for two subject areas used in teacher librarian training. To address question 2, in Section 4 we develop an application of metadata education through a two-year project: constructing an environmental studies database for use in teaching teacher librarians in Japanese educational settings. Also for question 2, we conduct a preliminary survey of what students anticipated needing from the database in Section 5. In Section 6, we discuss what these results reveal about the former two questions, and in Section 7 we make concluding remarks and identify future tasks.

\section{The Regulation of Subject and Contents}

The overall curriculum for teacher librarians in Japan is regulated by the MoE. The regulation includes mandatory subjects and contents. If a person wants to receive licensure as a teacher librarian, he or she must hold a teacher licensure and complete either a "teacher librarian seminar" or a summer-intensive course in a university or college. The intensive course is offered in limited locations. Alternatives to this intensive course are similar programs offered in many universities or colleges. The corresponding program is comparable to the intensive course. Students who complete the program are able to present this certification of completion to the universities or colleges that offer the intensive course.

Whether training consists of the intensive-course or an alternative program, the course subject and contents are governed by the same regulation. All institutions that train teacher librarians are mandated by MoE to offer five subjects (Ministry of Education, 1998). There are no official 
English names for these five subjects. For example, our university translates these subjects as follows:

1. Management of Schools, School Libraries, and Media Centers

2. Instruction for Learning in School Libraries and Media Centers

3. Organization of School Library Media

4. Study of the Relationship between Reading and Humanity

5. Information Media and Use

The MoE also prescribes goals and contents for these subjects. Subject 1 is a general understanding of school library management and of the meaning of education in the school library. Subject 2 is an understanding the applications of the school library in educational guidance. Subject 3 is an understanding and development of school library media. Subject 4 is an understanding of the philosophy and methodologies of reading education with regard to theories of child development and pedagogy. Subject 5 is aimed at understanding the specification and application of various school library media.

In particular, Subjects 3, Organization of School Library Media (OSML) and 5, Information Media and Use (IMU) are focused on school library media. The two subjects should include the contents listed in Table 1.

Table 1: The regulation of contents about teacher librarian subjects by the Japanese Ministry

\begin{tabular}{|c|c|}
\hline \multicolumn{2}{|c|}{ of Education } \\
\hline Subject Name & Contents \\
\hline Organization of School Library Media & $\begin{array}{l}\text { - Variations and specifications of school library } \\
\text { - } \text { - Chedia } \\
\text { - Organize and formation of school library media } \\
\text { - Significance and features of classification } \\
\text { - Nihon Decimal Classification } \\
\text { - Significance and features of cataloging - } \\
\text { Nihon Cataloging Rules }\end{array}$ \\
\hline
\end{tabular}




\begin{tabular}{|c|c|c|}
\hline & $\bullet$ & $\begin{array}{l}\text { - Mechanized cataloging } \\
\text { Location of school library media in a variety } \\
\text { of learning environments }\end{array}$ \\
\hline Information Media and Use & $\begin{array}{l}\bullet \\
\bullet \\
\bullet\end{array}$ & $\begin{array}{l}\text { Information science and human society } \\
\text { (including the development and evolution of } \\
\text { information media) } \\
\text { Significance and choice of information media } \\
\text { Utilizing audiovisual media } \\
\text { Utilizing computers } \\
\text { - Utilizing educational software } \\
\text { - Information retrieval using a database } \\
\text { - } \quad \text { Retrieval and offering of information } \\
\text { using the Internet } \\
\text { Copyright and school library media }\end{array}$ \\
\hline
\end{tabular}

Because mechanized cataloging and choice of information media are addressed by these subjects, it is implicit that metadata must be covered within both OSML and IMU.

\section{Textbook Review}

The topic of metadata is not explicitly addressed by the MOE regulation but the topic is implicit in Subjects 3 and 5 . Because the study of metadata is a necessary part of teacher librarian education, we shall now look more carefully into the treatment of metadata in Japanese textbooks for teacher librarians. We have reviewed six textbooks of OSML and IMU.

OSML textbooks:

1. Midorikawa, N., Yamamoto, J., \& Nimura, K. (2000). Gakkō toshokan media no kōsei (second edition). Tōkyō: Gakubunsha.

2. Shimura, H., \& Tendō, S. (2009). Gakkō toshokan media no kōsei to sono soshikika. Tōkyō: Seikyūsha.

3. "Series Gakkō toshokan Gaku” Henshū linkai. (2010). Gakkō toshokan media no kōsei. Tōkyō: Zenkoku Gakkō Toshokan Kyōgikai.

4. Kita, K., \& Hirai, T. (2012). Gakko toshokan media no kosei(revised edition). Tōkyō: Hōsōdaigakukyōikushinkōkai. 
5. Oda, M., \& Asahina, D. (2015). Gakkō toshokan media no kōsei. Tōkyō: Jusonbō.

6. Shimura, H., \& Ishida, Y. (1999). Gakkō toshokan media no kōsei. Tōkyō: Jusonbō.

IMU textbooks:

1. Yamamoto, J., \& Nimura, K. (2010). Jōhō media no katsuyō (second edition). Tōkyō: Gakubunsha.

2. Kobayashi, M. (2005). Ta media wo kastuyō suru chikara wo hagukumō. Tōkyō: Poplar publishing.

3. Zenkoku Gakkō Toshokan Kyōgikai. (2010). Jōhō media no katsuyō. Tōkyō: Zenkoku Gakkō Toshokan Kyōgikai.

4. Yamamoto, J., \& Kitani, Y. (2010). Jōhō media no katsuyō. Tōkyō: Hōsōdaigakukyōikushinkōkai.

5. Iguchi, I., \& Koga, S. (2002). Jōhō media no katsuyō. Tōkyō: Jusonbō.

6. Shimura, H., Tendō, S., \& Nakayama, S. (2009). Jōhō media no katsuyō to tenkai (revised edition). Tōkyō: Seikyūsha.

The results of textbook review are shown in Table 2.

Table 2: Treatment of metadata in teacher-librarian textbooks

\begin{tabular}{|l|l|}
\hline \hline \multicolumn{2}{|c|}{ Information Media and Use } \\
\hline Topic & Number of Textbooks \\
\hline Brief identification & 2 \\
\hline Nothing & 4 \\
\hline \multicolumn{2}{|c|}{ Organization of School Library Media } \\
\hline Topic & Number of Textbooks \\
\hline Detailed treatment & 2 \\
\hline Brief identification & 1 \\
\hline Nothing & 2 \\
\hline
\end{tabular}

Two of the six IMU textbooks contain a brief introduction to metadata. The following quotation is an example: "metadata are general document properties of HTML which include title of document, creator, data and so on." (Yamamoto and Kitani, 2010, p. 182) This identification is very simple. Otherwise, the rest of the textbooks make no mention of metadata. 
Two of the five OSML textbooks contain a detailed definition and exercise questions about metadata. Two of the five books use almost the same description. These textbooks contain information about metadata standards (DCMES), search systems for metadata (Subject Gateway), and contents management for learning (Learning Object Metadata). One of the five textbooks provided a brief definition of metadata. This textbook mentions the Dublin Core and some examples.

As seen from the above, a brief introduction to metadata is provided in the discussion of the structure of HTML in IMU textbooks. Metadata are covered more extensively in OSML textbooks.

We can draw three conclusions from our study of textbooks: 1. Metadata are mentioned in IMU and OSML textbooks. 2. The topic of metadata usually consists only of a brief definition. 3 . None of the textbooks contain exercises using metadata or cover creating or managing metadata.

\section{Making an Environmental Studies Database}

Our research was conducted as part of an "environmental humanity forum" in Shirayuri University. The purpose of the forum is the development of a new academic interdisciplinary area based on the relationship between the environment and human behavior.

In 2013-2014, a former project (The 2013 project) of our forum evaluated educational resources of the Shirayuri University campus, a large green wooded campus that formerly served as a medicinal garden. The 2013 project aimed to desterilize the space for university education and organized the campus via historical, natural, cultural, and literary concepts. The project included several lectures and classes. For example, the project offered a lecture about the historical literature on the diversity of vegetation on campus and a class on drawing campus vegetation. Another class focused on exploring the campus environment in which students conducted fieldwork to classify plants and flowers according to color, sound, fragrance, and names. They annotated the campus map with this information.

The project linked this information with data on geographical points and published a campus environment map in 2014 (Horii et al., 2014). Figure 1 shows an example of the mapping of 
tree growth (Horii et al., 2014, p. 59). However, the coursework and maps have not been used in university education since the project ended. The book documents important information, but provides no tool for the retrieval of this information.

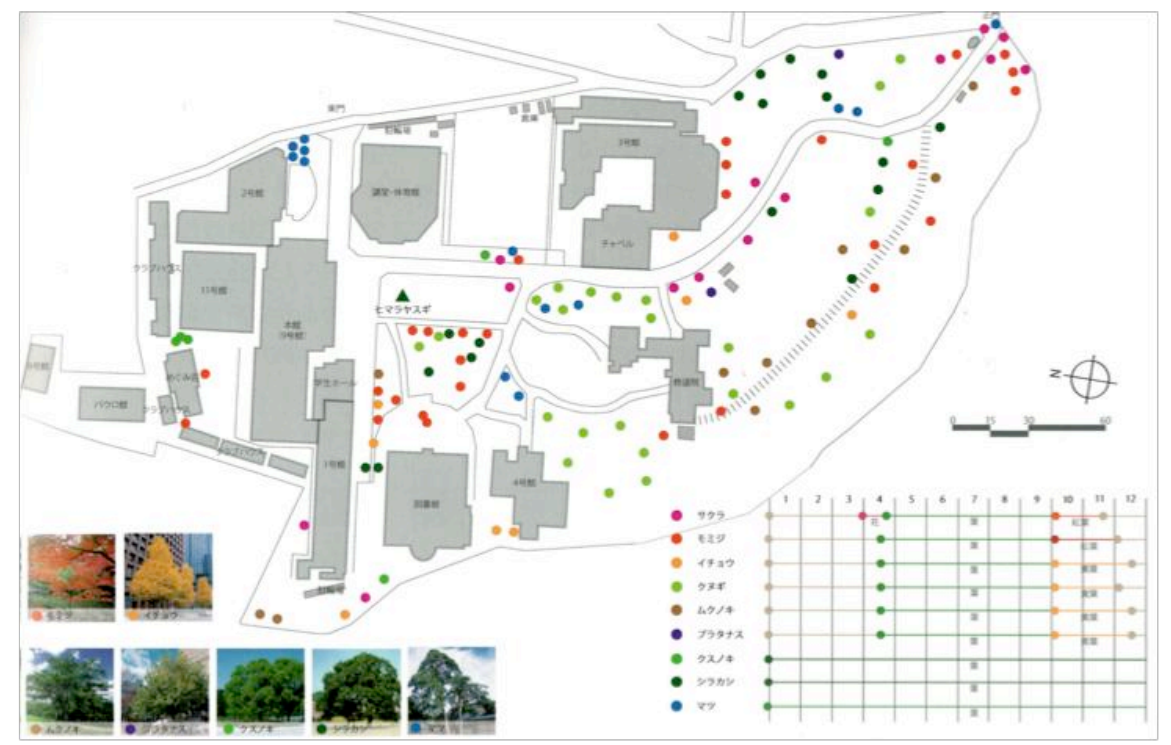

Figure 1: 2013 fieldwork mapping (tree growth)

Our project is part of a larger educational project of Shirayuri University in 2015-2016. The goal of our project was developing an environmental studies database and putting it to practical use. The first year of the two-year project developed an environmental studies database based on data accumulated during the 2013 project.

The database includes various types of data, including geographical latitude and longitude. We designed the application so that the database could be used as part of a lecture on metadata education.

We converted the map into an online database including the geographical information. Table 3 shows a sample sheet for the data conversion. Every data point contains related latitude and longitude. Some data points also have data for codes for color, fragrance, pleasure/displeasure, and sound.

Table 3: A sample sheet for data conversion

\begin{tabular}{|l|l|l|l|l|l|l|}
\hline Name & Latitude & Longitude & Color & Color & Fragrance & Pleasure / \\
\hline
\end{tabular}




\begin{tabular}{|c|c|c|c|c|c|c|}
\hline & & & $\begin{array}{c}\text { Code: } \\
\text { (Spring) }\end{array}$ & $\begin{array}{c}\text { Code: } \\
(\text { Summer })\end{array}$ & Displeasure \\
\hline A1 & 139.5824897 & 35.6668783 & $\# 7$ ebeab & $\# 7 b 8 d 42$ & & 323,324 \\
\hline A2 & 139.582361 & 35.6668761 & $\# 7$ ebeab & $\# 7 b 8 d 42$ & 109 & 323,324 \\
\hline A3 & 139.5822001 & 35.6668892 & $\# 7$ ebeab & $\# 004 d 25$ & 106,109 & $\begin{array}{c}304,305 \\
306\end{array}$ \\
\hline A4 & 139.5821705 & 35.6667802 & \#7ebeab & $\# 004 d 25$ & 106,109 & $\begin{array}{c}304,305, \\
306\end{array}$ \\
\hline
\end{tabular}

The main function of the database is to show the point data in web mapping using Google Map API. Figure 2 shows a screen capture of environmental studies database. In this example, the location indicated with the red pointer has data for spring color, latitude, and longitude, and is therefore displayed in the Google Map.

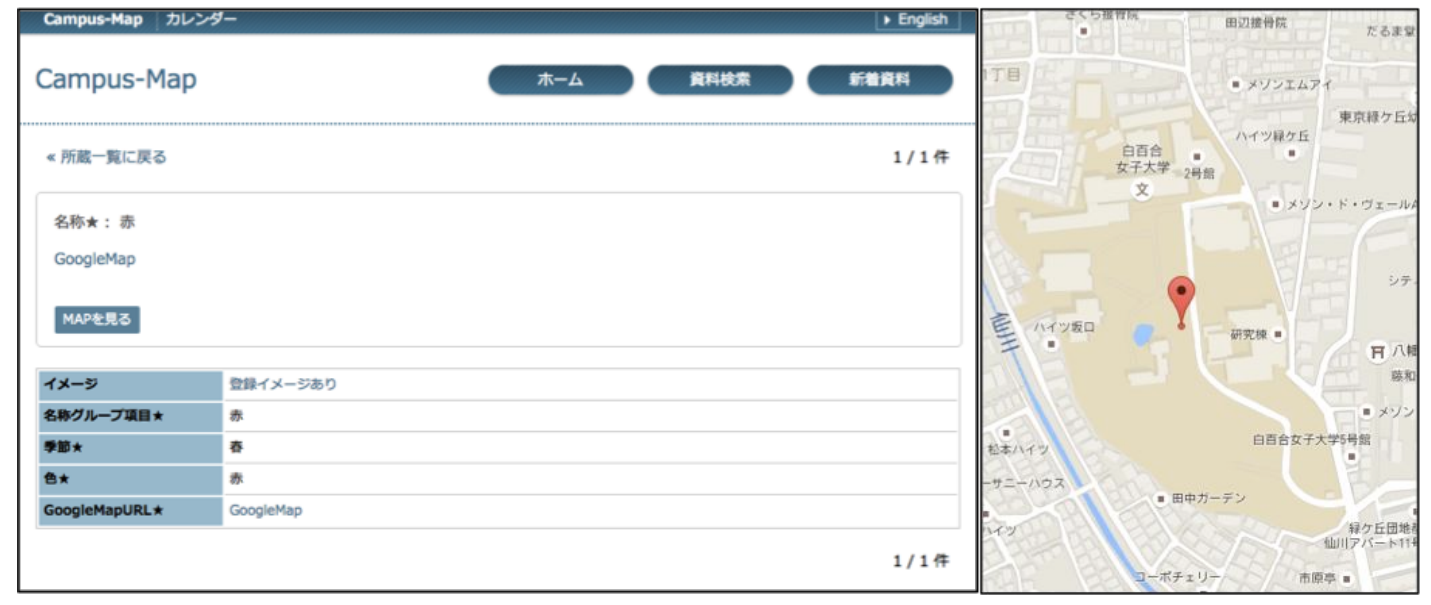

Figure 2: A screenshot of the environmental studies database

There were two problems in the conversion process. The first problem concerns the conversion of raw data to latitude and longitude. Students in the 2013 project gathered various kinds of data as they walked through the campus. Some of students mapped vegetation, other students mapped flavor. Vegetation can be pinpointed by latitude and longitude, whereas flavor data cannot. Flavor data are not point data, but range data. We have therefore estimated an alternative point datum based on the range data. The second problem relates to the variations in the data. Some data points have many types of data, including vegetation, color, and sound. Other data points have only color. There are variations in the richness of data 
collected for each data point. This is caused by the fact that students only collected data on what interested them. If the students were not interested in a particular aspect, it was not documented, whether or not data existed for that aspect.

\section{Survey of Students}

Before using the database in a class for teacher librarian education, we conducted a preliminary survey of what students anticipated needing from the database.

Although it would be proper to survey to students in a teacher librarian course, we surveyed twenty undergraduate students enrolled in a course that would prepare them to be certified as librarians, as it was not possible to survey teacher librarian students during our limited study period. We believe that librarian students are a valid substitute population.

In the preliminary survey, we demonstrated the environmental studies database and ascertained what students wanted to learn from the database. We asked multiple choice questions using a web survey tool. We asked twenty students for what they would want to accomplish using the environmental studies database, including

1. Trying additional data to the database

2. Collecting data via campus walking

3. Lecturing mechanism of the database from a manufacturer

4. Using the database and discussing potential uses of the database in education.

The results of the survey are shown in Table 4.

Table 4: Number of the students would want to accomplish using the database

\begin{tabular}{|l|c|}
\hline & Number of students \\
\hline 1. Trying additional data to the database & 2 \\
\hline 2. Collecting data via campus walking & 16 \\
\hline 3. Lecturing mechanism of the database from a manufacturer & 10 \\
\hline $\begin{array}{l}\text { 4. Using the database and discussing potential uses of the } \\
\text { database in education. }\end{array}$ & 15 \\
\hline
\end{tabular}


The results of the survey showed that the majority of students favored using the database to gather data via campus walking and to discuss potential uses of the database in education.

\section{Analysis and Discussion}

This research has four major findings. First, the evaluation of a regulation of subject content by

MoE, suggested that metadata is an important aspect of OSML and IMU. Second, the textbook review indicated that some IMU textbooks only define metadata, whereas some of OSML textbooks discuss exercise questions on the creation and management of metadata. Third, in the process of constructing a database, we identified two problems: first, converting raw data to latitude and longitude, and second, variations in the data collected. Fourth, a survey of students indicated that they favored using the database to assist in gathering data via campus walking and discussing potential uses of the database in education.

The MoE regulation is vague with regard to the topic of metadata. The regulation is comprehensive is not frequently amended. Recent amendments did not include metadata education. Some textbooks have included metadata definitions and exercises. Although some textbooks present nothing about metadata, these textbooks are older. The newer textbooks do address metadata. If these textbooks are subjected to later revisions, metadata should be an essential topic in OSML and IMU.

Our survey indicated that more applications and potential uses of metadata in education need to be addressed. In conclusion, we have recommended that teacher librarian education cover not only the definition of metadata but also its application in various situations.

\section{Further Study}

In April 18 of this year we surveyed ten undergraduate students in a course that would prepare them to be certified as teacher librarians. We conducted the survey to ascertain what students understand about metadata. The results of the survey showed that none of the students could define metadata.

We are currently working with teacher librarians to implement the database in the classroom. For example, we offer a lecture in IMU that shows the students how to create a guidance plan for elementary education using our database. The lecture will include both the definition of 
metadata and application. In the future, we will develop curricula and sample syllabi that enable librarians to integrate the database into subject-based coursework.

\section{Acknowledgements}

We would like to gratefully thank Mitsubishi Jisho Sekkei Inc. and Braintech Inc., who provided technical help and sincere encouragement. This work was supported by the "Education Program Promotion Grant of Shirayuri University 2015-2016"

\section{References}

American Association of School Librarians. (2009). Standards for the 21st-century learner in action. Chicago: American Association of School Librarians.

The Dublin Core Metadata Initiative. (2012). Dublin Core Metadata Element Set, Version 1.1 Retrieved March 15, 2016, from http://dublincore.org/documents/dces/

Feather, J., \& Sturges, R. P. (2003). International encyclopedia of information and library science. London: Routledge.

Kasai, Y. (2006). School library challenge in Japan-LIPER-SL: Library and information professions and education renewal, school library research group report. Proceedings of the Asia-Pacific Conference on Library \& Information Education \& Practice 2006 (A-LIEP 2006) (pp. 436-444). Singapore: School of Communication \& Information, Nanyang Technological University.

Kudo, K. (2014). An experiment in librarian or teacher librarian training programs to make library pathfinders [in Japanese] Memoirs of Beppu University, 55, 137-149.

Maeda M., Tokuda E. (2012). The Course to Train Teacher Librarians who Conduct the NIE: Newspaper in Education: The Development, the Enforcement and the Evaluation of the Model Curriculum Japan journal of school librarianship, 14, 63-76.

Matsuzaki H., Shibata M. (2012). Study of textbooks for teacher-librarians: "Use of Information Resources" and "Organization of School Library Resources" [in-Japanese] The Library world (Quarterly journal of the Japan Institution for Library Science), 64(2), 136-141.

Ministry of Education. (1998). (Supplement 2) the aims and contents of the teacher librarian intensive seminar [in-Japanese] Retrieved March 15, 2016, from http://www.mext.go.jp/a_menu/shotou/dokusho/link/1327211.htm

Sakai, C., Nakamura, Y., \& Kitamura, Y. (2002). Japanese librarians learning from American school librarianship (May/June 2002). MultiMedia Schools Magazine. Retrieved May 9 , 2016, from http://www.infotoday.com/MMSchools/may02/sakai_nakamura_kitamura.htm

\section{Biographical note}


Fukuji Imai is an associate professor of Shirayuri University in Tokyo. He is a scholar of library information science. His research interests include history of Japanese school library and methodology in information studies. He earned a Ph.D. in Education at University of Tokyo. Recent work includes a report "A Seminar of Library Information System on Cloud Computing Services in University Class"(2015), and an article "School Library in American School Curriculum Reforms: 1920 s to 1940s Reforms and the Introduction to Japan in Occupation Era"(2012).

Anne McKnight is a scholar of postwar Japanese literature and film. She earned a PhD in Comparative Literature at UC Berkeley. Recent work includes a monograph on the Japanese writer Nakagami Kenji (University of Minnesota Press, 2011), essays on Japanese feminist aesthetics and censorship (Duke, 2016), black robots in Japan (Lexington, 2015), and Japanese "pink" films (Camera Obscura, 2012, winner of the Katherine Singer Kovács Essay Award from Society for Cinema and Media Studies); she won an award for Teaching with Technology from the University of Southern California in 2011. She is an Associate Professor at Shirayuri University.

Kuniharu Tabata is a president at Shirayuri University in Tokyo. His research interests include philosophy and the science of religion. He published a book about a view of life and death by the interpretation of Japanese literature (Kanashimi_wo_Sasaeru_Kotoba:

Kojiki_kara_Bashō_made, 2015), and wrote " The Analysis of the Role of Religion in the Tale of Genji, Specifically in Relation to the Tale of Nyo-Sannomiya and Kashiwagi"(2013), and "The undercurrent of Japanese ideas of life and death (2): the representation of souls in The tale of Genji"(2011)

Shinji Iwamasa is a professor of English at Shirayuri University in Tokyo and former visiting scholar at Stanford University. His research interests include critical theory, ecocriticism and peace studies. He edited and translated_The Memorable Quotations of Henry David Thoreau_(Bunyusha, 2009), and co-edited and translated _The Great

Peacemakers_(Iwanami Shoten, 2009). His recent publications include "The Mechanics of Place in the Writings of Rachel Carson"(2010), and "A Study of Thoreau's Prayer in the Writings of Terry Tempest Williams."(2013) 